\title{
Synergic antistaphylococcal properties of lactoferrin and lysozyme
}

\author{
E. C. LEITCH and M. D. P. WILLCOX \\ Cooperative Research Centre for Eye Research and Technology, University of New South Wales, 22-32 King \\ Street, Randwick 2031, NSW, Australia
}

\begin{abstract}
Staphylococcus epidermidis colonises a wide range of implanted prosthetic devices, but rarely contact lenses - despite a similarity in material composition. A conceivable explanation for this anomaly is the action of the tear defences, including the constitutive proteins lactoferrin and lysozyme. Therefore this study investigated the effect of lactoferrin, lysozyme and serum on the growth of $S$. epidermidis isolates in artificial tear fluid. Whether supplemented with serum alone or serum with either apolactoferrin or lysozyme, this medium induced a similar, strain-variable effect. However, simultaneous addition of these proteins induced a greater bactericidal or bacteristatic effect. Of those strains killed by the concerted action of apolactoferrin and lysozyme, the absence of serum led to a further increase in the bactericidal effect, whereas strains displaying bacteriostasis were unaffected by serum. Iron saturation of lactoferrin reversed the antimicrobial synergy of apolactoferrin and lysozyme. These results show synergy between lactoferrin and lysozyme which is dependent on the iron limitation of lactoferrin. As a bactericidal mechanism, this synergy is augmented by serum, but bacteriostasis remains unaffected by serum supplemention. Thus, the combination of lysozyme and lactoferrin may partly explain the low level of contact lens colonisation by S. epidermidis in vivo.
\end{abstract}

\section{Introduction}

Staphylococcus epidermidis is a major pathogen of implanted medical devices such as intravenous catheters [1] and intraocular lenses [2]. Despite a similarity in the material composition of implanted biomaterials and contact lenses, this organism has rarely been associated wtih contact lens-related infections [3]. We hypothesised that this anomaly was due to tear fluid defence proteins which bathe the anterior surface of the eye. As well as adaptive components such as IgA [4], tears contain an array of non-adaptive but interactive antimicrobial factors including complement [5], lactoferrin [6] and lysozyme [4]. An in-vitro examination of the individual effects of these substances has shown that $S$. epidermidis strains resist complement-mediated killing and the action of iron-limited (apo-)lactoferrin or lysozyme [7].

Previous studies have demonstrated an irreversible antimicrobial action of apolactoferrin unrelated to its

Received 1 Aug. 1997; revised version accepted 15 Jan. 1998.

Corresponding author: Dr E. C. Leitch. iron-chelating capacity [8, 9], including a bacteriostatic effect on a clinical strain of $S$. epidermidis [10]. This action is thought to be caused by the highly cationic region near the $\mathrm{N}$-terminus of lactoferrin [11] which can be isolated by proteolysis; the resulting peptide is referred to as lactoferrin [11]. The mechanism of action of lactoferrin on gram-negative bacteria has been demonstrated to involve the release of lipopolysaccharide (LPS) [12] and a decrease in the semi-permeable nature of the outer membrane [13]. The basis for the action of this protein on grampositive bacteria is unknown.

In comparison with other body fluids, human tears contain the highest concentration of lysozyme [14]. This protein is a muramidase that cleaves peptidoglycan [14]. Also, lysozyme has been shown to activate pre-existing autolytic enzymes of $S$. aureus in acidic conditions [15]. Lysozyme activity has been shown to be additive to the action of apolactoferrin on gramnegative bacteria [16].

Functionally active complement components have been found in closed eye tears at concentrations of $1-20 \%$ of their plasma levels, depending on the individual 
complement protein. The alternative pathway of complement, which can be activated directly by bacteria, was found to be present in normal human tears [5]. Previous results have indicated that strains of $S$. epidermidis are resistant to complement killing in serum $10 \%$, higher than the in-vivo tear concentration of most complement proteins [7]. Ethylenediaminetetraacetic acid (EDTA), which has been shown to release LPS in a manner similar to that of lactoferrin, has rendered resistant gram-negative bacteria sensitive to complement [17].

The individual effects of complement, apolactoferrin and lysozyme on strains of S. epidermidis [7] and the synergy between apolactoferrin and lysozyme for gram-negative bacteria have been described previously [16]. This study examined the interactive effects of these defence proteins in an artificial tear fluid on various $S$. epidermidis isolates. The role of iron limitation of lactoferrin in this medium was explored.

\section{Materials and methods}

\section{S. epidermidis strains}

The following $S$. epidermidis strains were assayed: ATCC 35983 and ATCC 14990; three ocular strains isolated at the Cornea and Contact Lens Research Unit, University of New South Wales from asymptomatic subjects wearing soft contact lenses (SE3, SE4 and SE5); and three isolates from infected biomaterials (SE7 and SE13, central line tips; SE14, swan-fent tip) which were kindly supplied by the Prince of Wales Hospital, Sydney, Australia. All strains were identified as $S$. epidermidis by a previously described identification procedure [18] and stored at $-70^{\circ} \mathrm{C}$ until required.

\section{Artificial tear fluid}

Artificial tear fluid was prepared as described previously [19], supplemented or unsupplemented with pooled normal human serum $2 \%$, human milk lactoferrin (Sigma) $1.8 \mathrm{mg} / \mathrm{ml}$ and egg-white lysozyme (Sigma) $5.4 \mathrm{mg} / \mathrm{ml}$. Artificial tear fluid was selected as a suitable medium to evaluate the effects of various tear antimicrobial factors on $S$. epidermidis as it contains similar salts, lipids and proteins to tears in comparable concentrations [19]. Lactoferrin and lysozyme are present in closed eye tears at a concentration of $1.8 \mathrm{mg} / \mathrm{ml} \mathrm{[20].} \mathrm{Chick} \mathrm{egg-white} \mathrm{lysozyme} \mathrm{has}$ approximately one-third the activity of its human counterpart [21] and the supplemented concentration of $5.4 \mathrm{mg} / \mathrm{ml}$ reflects lysozyme activity in vivo. Human milk lactoferrin was added at $1.8 \mathrm{mg} / \mathrm{ml}$. The effect of serum $2 \%$ was evaluated in this study as the alternative complement pathway has been shown to be active in closed eye tears with most complement components being present at concentrations of $0.2-2.2 \%$ of their plasma level [5]. The effect of $31.25 \mu \mathrm{M}$ EDTA and lysozyme $5.4 \mathrm{mg} / \mathrm{ml}$ on strain SE5 was assessed to confirm the absence of EDTA activity in apolactoferrin preparations.

\section{Ferric ion content of lactoferrin}

Lactoferrin was iron-limited as described previously [22]. Briefly, lactoferrin was dialysed three times against EDTA (Merck, Kilsyth, Australia) $1 \%$ in phosphate buffer $\left(0.1 \mathrm{M} \mathrm{Na}_{2} \mathrm{HPO}_{4}, \mathrm{pH}\right.$ 4.6; Bacto Laboratories, Liverpool, Australia) followed by dialysis (1 in 1000 dilution) twice against distilled $\mathrm{H}_{2} \mathrm{O}$. Lactoferrin was analysed for contaminating EDTA spectrophotometrically at $195 \mathrm{~nm}$ and the absorbance of lactoferrin preparations was found to be less than the absorbance of $31.25 \mu \mathrm{M}$ EDTA. The amount of ferric ions bound to lactoferrin was determined by a previously published method [23] whereby reduced protein was precipitated and ferric ions detected with ferrozine and neocuproin (Sigma). This was miniaturised for use in a 96-well microtitration plate and analysed spectrophotometrically at $570 \mathrm{~nm}$ with a plate reader (Model 3550, BioRad, Regents Park, Australia).

\section{Growth conditions}

Each strain was inoculated into $10 \mathrm{ml}$ of Tryptone Soya Broth (TSB; Oxoid, Melbourne, Australia) and grown overnight at $37^{\circ} \mathrm{C}$ until the stationary phase had been reached. The bacteria were then washed three times in phosphate-buffered saline (PBS; $\mathrm{NaCl} 8 \mathrm{~g} / \mathrm{L}$; $\mathrm{Na}_{2} \mathrm{HPO}_{4} \cdot 2 \mathrm{H}_{2} \mathrm{O} \quad 1.14 \mathrm{~g} / \mathrm{L} ; \quad \mathrm{KCl} \quad 0.2 \mathrm{~g} / \mathrm{L}, \quad \mathrm{KH}_{2} \mathrm{PO}_{4}$ $0.2 \mathrm{~g} / \mathrm{L} ; \mathrm{pH} 7.2$ ) by centrifugation and resuspended in PBS to an optical density of 0.1 at $660 \mathrm{~nm}$. Bacterial suspensions were added ( 1 in 10$)$ to various artificial tear fluid types and incubated with rotation for $10 \mathrm{~h}$ at $37^{\circ} \mathrm{C}$. Samples $(20 \mu \mathrm{l})$ were extracted immediately on addition of bacteria and thereafter at 2.5 -h intervals. These samples were diluted (1 in 100) in PBS, vortex mixed for $10 \mathrm{~s}$, then sonicated at $50 \mathrm{~Hz}$ for $15 \mathrm{~min}$ with an ultrasonic cleaner (Unisonics, Sydney, Australia). Serial dilutions were performed and three $20-\mu l$ samples from each dilution were plated on nutrient agar (Oxoid) to determine the number of viable bacteria [24].

\section{Statistical analyses}

Statistical analyses were performed by Student's $t$ test.

\section{Results}

\section{Iron content of artificial tear fluid types}

The average free ferric ion content of artificial tear fluid types, apolactoferrin and non-iron-limited (holo)lactoferrin is shown in Table 1. Lactoferrin (mol.wt 80000 ) was added to artificial tear fluid at a concentration of $1.8 \mathrm{mg} / \mathrm{ml} \quad(22.5 \mu \mathrm{M})$, requiring $45 \mu \mathrm{M}(2.52 \mu \mathrm{g} / \mathrm{ml})$ of ferric ions to fully saturate this protein which binds two ferric ions per molecule. 
Table 1. Ferric ion content in artificial tear fluid and bound to lactoferrin

\begin{tabular}{|c|c|c|c|}
\hline Medium & $\begin{array}{l}\text { Ferric ion content } \\
\qquad(\mu \mathrm{g} / \mathrm{ml})\end{array}$ & Medium & $\begin{array}{l}\text { Ferric ion content } \\
(\mu \mathrm{g} / \mathrm{ml})\end{array}$ \\
\hline ATFS & $0.47^{*}(0.00)$ & ATF & $0.49^{*} \quad(0.00)$ \\
\hline ATFS + apoLF & $0.26^{\dagger} \quad(0.07)$ & $\mathrm{ATF}+\mathrm{apoLF}+\mathrm{LZ}$ & $0.43^{*}(0.00)$ \\
\hline ATFS + LZ & $0.44^{*}(0.00)$ & ATFS + holoLF & $3.31^{\dagger}(1.63)$ \\
\hline ATFS + apoLF+LZ & $0.28^{*}(0.00)$ & ATFS+holoLF+LZ & $0.28^{\dagger} \quad(0.46)$ \\
\hline apoLF & $0.22^{\dagger} \quad(0.01)$ & holoLF & $3.10^{\dagger} \quad(0.42)$ \\
\hline
\end{tabular}

* Results represent the mean (SD) of two experiments.

${ }^{\dagger}$ Results represent the mean (SD) of two experiments for each of two media.

Hence apolactoferrin $(0.22 \mu \mathrm{g} / \mathrm{ml})$ is approximately $8.7 \%$ saturated with ferric ions and hololactoferrin $(3.1 \mu \mathrm{g} / \mathrm{ml})$ is fully saturated.

\section{Sonication}

Cell clustering was displayed by $S$. epidermidis strains grown in artificial tear fluid. Clustering was considered likely to affect viable counts and was reduced by sonication. Fig. 1 shows the cluster sizes of isolates sonicated for 0 or $14 \mathrm{~min}$ after incubation in artificial tear fluid supplemented with serum for $10 \mathrm{~h}$. The average cluster size for each strain decreased after sonication, although strain SE14 still retained an average of four cells/cluster. The viability of all strains was retained after sonication.

\section{Growth in artificial tear fluid containing serum}

The difference in bacterial numbers between the initial inoculum and after growth for $10 \mathrm{~h}$ in artificial tear fluid containing serum only (ATFS) is shown in Table 2. ATFS was bactericidal for strains ATCC 14990, SE4 and SE13. Bacteriostasis was maintained for $2.5 \mathrm{~h}$ followed by a gradual decrease in numbers for a further $5 \mathrm{~h}$. This bactericidal effect was similar in ATFS containing apolactoferrin (ATFS+apoLF) or lysozyme (ATFS $+\mathrm{LZ})$. Compared with these three media, there was a significant $(p<0.05)$ increase in bacterial killing for these strains in ATFS containing both apolactoferrin and lysozyme (ATFS+apoLF+LZ) and a greater bactericidal effect. A bacteriostatic effect was observed for strains ATCC 35983 and SE3 and there was no statistically significant difference between different media. Strains SE5, SE7 and SE14 showed a similar growth in ATFS, ATFS+apoLF and ATFS+LZ. These strains showed a typical growth curve revealing the stationary phase attained by $7.5 \mathrm{~h}$. However, compared with the growth observed in these media, there was a significant decrease $(\mathrm{p}<0.01)$ in growth in ATFS +apoLF + LZ. Strain SE14 showed a similar growth pattern as before, but with lower bacterial

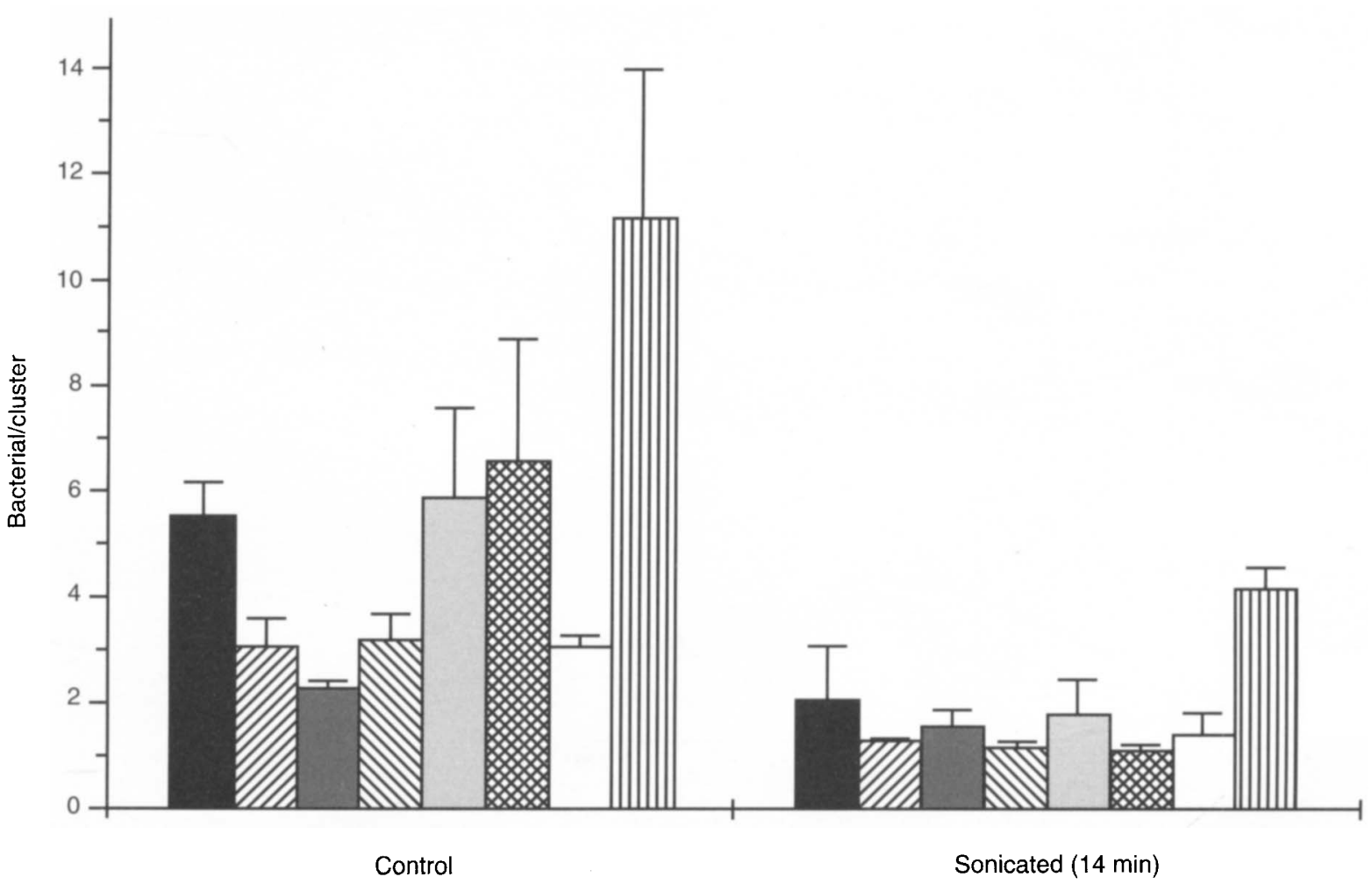

Fig. 1. Average number of bacteria/cluster after sonication for 0 or $14 \mathrm{~min}$ at $50 \mathrm{~Hz}$ after growth in artificial tear fluid plus serum. Results represent the mean (bar, SD) of 10 experiments. $\mathbf{\square}$, ATCC 14990; ATCC 35983; $\mathbf{\square}$, SE3; $\mathbb{Q}$,

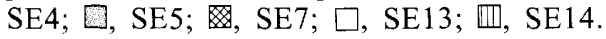


Table 2. Effect of apolactoferrin and lysozyme on bacterial numbers of S. epidermidis strains growing in artificial tear fluid

\begin{tabular}{|c|c|c|c|c|c|}
\hline \multirow[b]{2}{*}{ Strain no. } & \multicolumn{5}{|c|}{ Mean (SD) difference in bacterial numbers $\left(\log _{10} \text { bacteria } / \mathrm{ml}\right)^{*}$ in } \\
\hline & ATFS & ATFS+apoLF & ATFS + LZ & ATFS +apoLF $+\mathrm{LZ}$ & $\mathrm{ATFS}+\mathrm{LZ}+\mathrm{EDTA}$ \\
\hline ATCC 14990 & $-0.65(0.37)^{\dagger}$ & $-0.35(0.27)$ & $-0.67(0.50)$ & $-1.27(0.27)$ & \\
\hline ATCC 35983 & $+0.21(0.24)^{\ddagger}$ & $+0.21(0.26)$ & $+0.22(0.27)$ & $0.00(0.06)$ & $\ldots$ \\
\hline SE3 & $-0.15(0.20)$ & $-0.09(0.34)$ & $-0.26(0.23)$ & $-0.50(0.51)$ & $\ldots$ \\
\hline SE4 & $-0.48(0.09)$ & $-0.33(0.22)$ & $-0.71(0.27)$ & $-1.00(0.06)$ & $\cdots$ \\
\hline SE5 & $+1.02(0.07)$ & $+0.82(0.23)$ & $+1.02(0.11)$ & $+0.18(0.28)$ & $+1.03(0.03)$ \\
\hline SE7 & $+0.78(0.09)$ & $+0.50(0.03)$ & $+0.66(0.12)$ & $+0.16(0.10)$ & $\ldots$ \\
\hline SE13 & $-0.39(0.21)$ & $-0.40(0.51)$ & $-0.23(0.28)$ & $-0.75(0.11)$ & $\ldots$ \\
\hline SE14 & $+0.92(0.07)$ & $+0.71(0.04)$ & $+0.71(0.10)$ & $+0.46(0.09)$ & $\ldots$ \\
\hline
\end{tabular}

ATFS + apoLF + LZ showed significant $(\mathrm{p}<0.05)$ differences in the final bacterial numbers from all other growth conditions for all strains with the exception of ATCC 35983 and SE3. ..., not tested.

${ }^{*}$ Results represent the mean of six experiments and are expressed as the difference between the initial inoculum and the final ( $\left.10 \mathrm{~h}\right)$ sample. †Negative data represent a decrease in bacterial numbers.

${ }^{\ddagger}$ Positive data represent an increase in bacterial numbers.

numbers attained at stationary phase; this medium was bacteriostatic for strains SE5 and SE7. Fig. 2 illustrates the growth displayed by strain SE5. The growth of strain SE5 in ATFS+LZ containing $31.25 \mu \mathrm{M}$ of EDTA was similar to the growth of this strain in ATFS $+\mathrm{LZ}$ alone and significantly $(\mathrm{p}<0.001)$ greater than that in ATFS +apoLF + LZ (Table 2). This indicates that EDTA potentially contaminating apolactoferrin $(<31.25 \mu \mathrm{M}$ by spectrophotometry) was not responsible for the synergy displayed between apolactoferrin and lysozyme.

\section{The effect of serum on growth}

Table 3 shows the extent of growth in ATFS unsupplemented with serum (ATF) and ATFS + apoLF $+\mathrm{LZ}$ lacking serum $(\mathrm{ATF}+\mathrm{apoLF}+\mathrm{LZ})$. Comparing growth of strains SE4 and SE13 in ATF with that in $\mathrm{ATF}+$ apoLF+LZ, there was a significant increase $(p<0.0001)$ in killing. For strains SE5 and SE7, there was a significant increase in bacterial numbers $(p<0.01)$ in ATF compared with that in ATF + apoLF + LZ. Growth in medium lacking serum (Table 3) was compared with that in serum-supple-

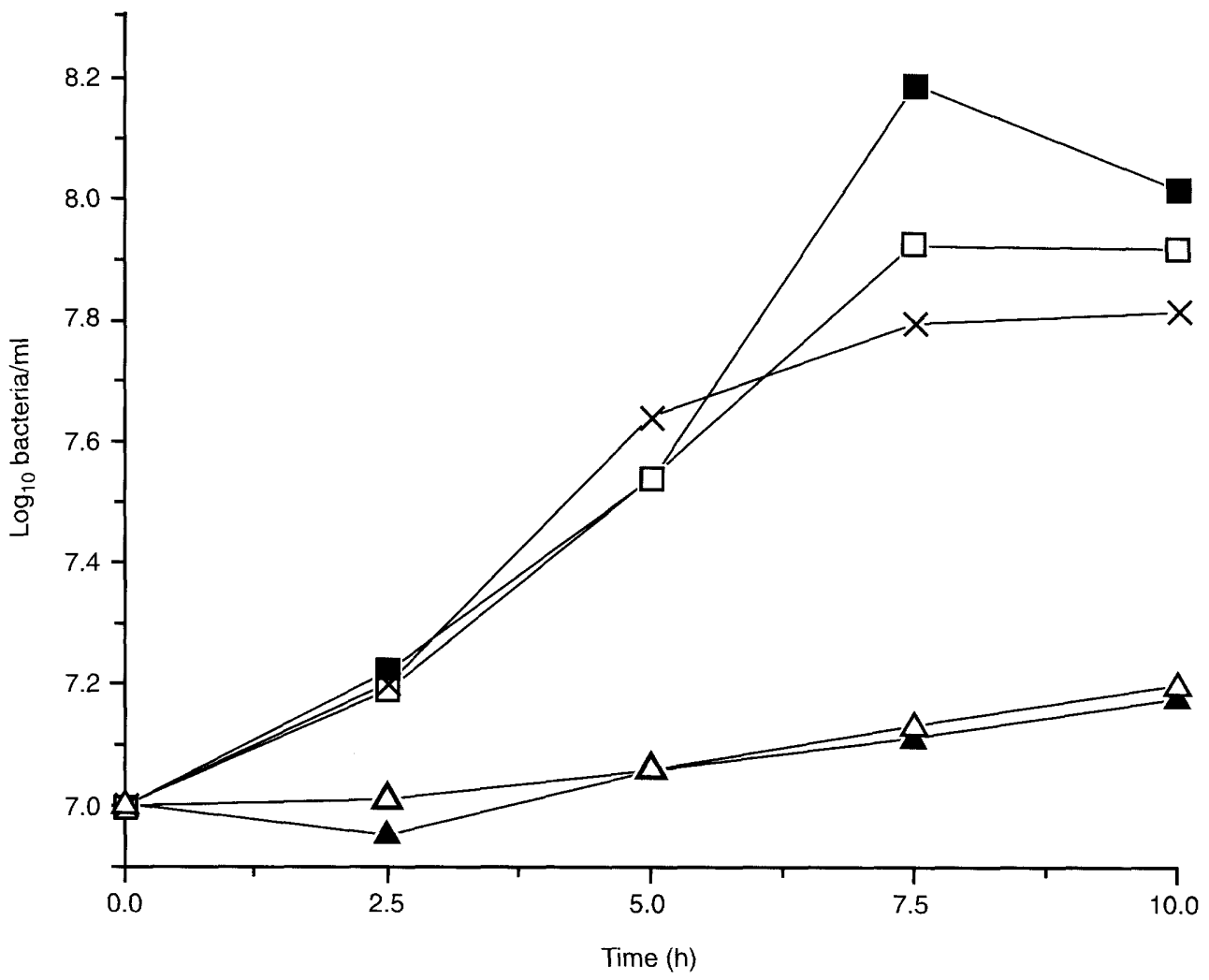

Fig. 2. Growth of strain SE5 over $10 \mathrm{~h}$ in artificial tear fluid supplemented with serum and lysozyme (ATFS $+\mathrm{LZ}$, $\mathbf{\square}$ ); serum, hololactoferrin and lysozyme (ATFS +holoLF $+\mathrm{LZ}, \square$ ); serum and apolactoferrin (ATFS+apoLF, X); serum, apolactoferrin and lysozyme $(A T F S+a p o L F+L Z, \Delta)$; or apolactoferrin and lysozyme (ATF+apoLF+LZ, $\triangle$ ). Results represent the mean of six experiments. 
Table 3. Effect of serum depletion of artificial tear fluid, with or without apolactoferrin and lysozyme, on viability of $S$. epidermidis strains

\begin{tabular}{lcc}
\hline & \multicolumn{2}{c}{$\begin{array}{c}\text { Mean (SD) difference in bacterial numbers }\left(\log _{10}\right. \\
\text { bacteria } / \mathrm{ml})^{*} \text { in }\end{array}$} \\
\cline { 2 - 3 } Strain no. & ATF & ATF+apoLF+LZ \\
\hline SE4 & $-0.07(0.06)^{\dagger}$ & $-1.78(0.03)$ \\
SE5 & $+1.08(0.29)^{\ddagger}$ & $+0.20(0.08)$ \\
SE7 & $+0.60(0.24)$ & $+0.11(0.06)$ \\
SE13 & $-0.03(0.03)$ & $-1.65(0.12)$ \\
\hline
\end{tabular}

ATF + apoLF $+\mathrm{LZ}$ showed a significant $(\mathrm{p}<0.01)$ difference in the final bacterial numbers from ATF for all strains.

$*^{*+}$ See footnote to Table 2 .

mented medium (Table 2). Bacteriostasis was maintained for strains SE4 and SE13 in ATF, with a statistically increased $(\mathrm{p}<0.01)$ survival compared with the bactericidal effect observed in ATFS. Conversely, $\mathrm{ATF}+\mathrm{apoLF}+\mathrm{LZ}$ caused a statistically increased $(p<0.0001)$ bactericidal effect on strains SE4 and SE13 compared with its serum-supplemented counterpart and growth curves were similar, but with continued killing after $7.5 \mathrm{~h}$ in the former medium. Growth of strains SE5 and SE7 was not statistically different in ATF compared with ATFS or in $\mathrm{ATF}+$ apoLF $+\mathrm{LZ}$ compared with its serum-supplemented counterpart, as illustrated in Fig. 2 for strain SE5, and similar growth curves were obtained.

\section{The effect of hololactoferrin on growth}

The effect of supplementing ATFS with hololactoferrin (holoLF) is shown in Table 4 . The bactericidal effect on strains SE4 and SE13 observed in ATFS+holoLF, which was slight but gradual for $7.5 \mathrm{~h}$, was further increased $(p<0.001)$ in ATFS+holoLF + LZ and continued for $10 \mathrm{~h}$. No significant data were obtained comparing growth of strains SE5 and SE7 in ATFS +holoLF and ATFS+holoLF+LZ. Growth in medium supplemented with hololactoferrin (Table 4) was compared with medium containing apolactoferrin (Table 2). There was no statistical difference in the growth of strain SE5 in ATFS + holoLF compared with ATFS + apoLF and similar growth curves were ob-

Table 4. Effect of hololactoferrin on bacterial numbers of $S$. epidermidis strains grown in artificial tear fluid with or without lysozyme

\begin{tabular}{lcc}
\hline & \multicolumn{2}{c}{$\begin{array}{c}\text { Mean (SD) difference in bacterial numbers }\left(\log _{10}\right. \\
\text { bacteria } / \mathrm{ml})^{*} \text { in }\end{array}$} \\
\cline { 2 - 3 } Strain no. & ATFs + holoLF & ATFs+holoLF+LZ \\
\hline SE4 & $-0.35(0.17)^{\dagger}$ & $-0.91(0.05)$ \\
SE5 & $+0.95(0.13)^{\ddagger}$ & $+0.92(0.16)$ \\
SE7 & $+0.81(0.10)$ & $+0.67(0.16)$ \\
SE13 & $-0.36(0.10)$ & $-0.86(0.06)$ \\
\hline
\end{tabular}

ATFs +holoLF + LZ showed a significant $(\mathrm{p}<0.001)$ difference in the final bacterial numbers from ATFs + holoLF for strains SE4 and SE 13 .

$*+$ See footnote to Table 2 . served. However, the growth of strain SE7 in ATFS +holoLF was increased statistically $(p<0.001)$ compared with growth in ATFS+apoLF. The antimicrobial effect of ATFS + apoLF + LZ on strains SE4, SE5 and SE7 was lost when holoLF was substituted for apoLF $(\mathrm{p}<0.05)$ with growth curves more closely resembling those observed without lactoferrin supplementation, as depicted in Fig. 2 for strain SE5. Although a similar effect was seen for strain SE13, it was not significant.

\section{Discussion}

This study has shown that apolactoferrin and lysozyme, at concentrations found in tears, exert antimicrobial synergy against isolates of $S$. epidermidis. An additive antimicrobial effect of lactoferrin and lysozyme toward various gram-negative bacteria has been shown [16], similar to the synergy displayed in this study against some $S$. epidermidis strains. Lactoferrin is a highly cationic protein [12] and this may be essential to its mechanism of action. It has been shown that lactoferrin is able to interfere with the LPS layer of gram-negative bacteria, increasing its permeability [12], in a similar way to that of EDTA, polymyxin B [12] and defensins [25]. This might allow greater accessibility of other antimicrobial factors such as lysozyme into the bacteria [16]. It is not known how lactoferrin affects grampositive bacteria; however, its polycationic properties suggest that it may interact with the anionic cell wall teichoic acid. Lactoferrin has been shown to have an antimicrobial effect similar to that of other polycationic peptides such as defensins [25] and polymyxin B [12]. One group of workers [11] has developed a synthetic analogue of the suspected active site of lactoferrin, which they have called lactoferricin. This peptide is also highly cationic and has been shown to have an increased antimicrobial effect in vitro compared with lactoferrin. The authors have speculated that the protease cleavage of lactoferrin to smaller peptide fragments may occur in vivo. Plasmin present in tears [26] may similarly cleave lactoferrin into these fragments.

Iron saturation has been shown to reverse the antimicrobial effects of apolactoferrin and it has been speculated that these antimicrobial properties occur independently of iron chelation $[8,9]$. Similarly, the present study has determined that hololactoferrin does not induce a synergic antimicrobial effect with lysozyme for $S$. epidermidis. This might be caused by the conformational change observed with ferric ion binding of lactoferrin [27]. Previous studies have shown that $S$. epidermidis ATCC 14990 requires $0.5 \mu \mathrm{M}$ iron $(0.03 \mu \mathrm{g} / \mathrm{ml})$ for growth in a defined medium [28]. This amount of free ferric ions was probably available in all artificial tear fluid types, even taking into account the amount bound in the lactoferrin molecules of ATFS + apoLF $+\mathrm{LZ}$. 
In-vitro studies have shown that apolactoferrin has an antimicrobial effect $[8,9]$ on various bacteria, including $S$. epidermidis [10]. The results of the present study indicated that apolactoferrin individually has no effect on strains of $S$. epidermidis grown in ATFS. This may be caused by a difference in growth conditions. One study [16] demonstrated that increasing the osmolality of the growth medium led to a decreased killing ability of apolactoferrin, an effect which was absent above 60 mOsm. Most body fluids have a higher osmolality than this. Tears, for example, have an osmolality of 304 mOsm [29] and the artificial tear fluid used in this study had a similar osmolality of 336 mOsm. This may explain the difference in results.

In summary, the growth of $S$. epidermidis strains in an artificial tear fluid was synergically reduced by the addition of apolactoferrin and lysozyme. This differed from the results of previous work in that apolactoferrin alone did not affect growth, which may reflect the type of growth medium used in the present study. This synergy was dependent on the iron limitation of lactoferrin, and serum augmented the bactericidal action for certain strains. Strain variation was evident, suggesting differences in either the type or amount of target sites expressed.

Grant support was received from the Australian Federal Government through the Cooperative Research Centres Program and from Vistakon, a division of Johnson and Johnson Vision Research Inc.

\section{References}

1. Tenney JH, Moody MR, Newman KA et al. Adheren microorganisms on lumenal surfaces of long-term intravenous catheters. Importance of Staphylococcus epidermidis in patients with cancer. Arch Intern Med 1986; 146: 1949-1954.

2. Driebe WT, Mandelbaum S, Forster RK, Schwartz LK, Culbertson WW. Pseudophakic endophthalmitis. Diagnosis and management. Ophthalmology 1986; 93: 442-448.

3. Cohen EJ, Gonzalez C, Leavitt KG, Arentsen JJ, Laibson PR Corneal ulcers associated with contact lenses including experience with disposable lenses. CLAO J 1991; 17: 173-176.

4. Chandler JW, Gillette TE. Immunologic defense mechanisms of the ocular surface. Ophthalmology 1983; 90: 585-591.

5. Willcox MDP, Morris CA, Thakur A, Sack RA, Wickson J, Boey W. Complement and complement regulatory proteins in human tears. Invest Ophthalmol Vis Sci 1997; 38: 1-8.

6. Kijlstra A. The role of lactoferrin in the nonspecific immune response on the ocular surface. Reg Immunol 1991; 3: 193-197.

7. Leitch EC, Willcox MDP. Interactions between the constitutive host defences of tears and Staphylococcus epidermidis. Aust NZ
$J$ Ophthalmol 1997; 25 Suppl 1: S20-S22.

8. Arnold RR, Cole MF, McGhere JR. A bactericidal effect for human lactoferrin. Science 1977; 197: 263-265.

9. Arnold RR, Russell JE, Champion WJ, Brewer M, Gauthier JJ. Bactericidal activity of human lactoferrin: differentiation from the stasis of iron deprivation. Infect Immun 1982; 35: 792-799.

10. Arnold RR, Brewer M, Gauthier JJ. Bactericidal activity of human lactoferrin: sensitivity of a variety of microorganisms. Infect Immun 1980; 28: 893-898.

11. Bellamy W, Takase M, Yamauchi K, Wakabayashi H, Kawase J, Tomita M. Identification of the bactericidal domain of lactoferrin. Biochem Biophys Acta 1992, 1121: 130-136.

12. Ellison RT, Giehl TJ, LaForce FM. Damage of the outer membrane of enteric gram-negative bacteria by lactoferrin and transferrin. Infect Immun 1988; 56: 2774-2781.

13. Erdei J, Forsgren A, Naidu S. Lactoferrin binds to porins $\mathrm{OmpF}$ and $\mathrm{OmpC}$ in Escherichia coli. Infect Immun 1994; 62: $1236-1240$.

14. Kuizenga A. Identification and characterization of proteins in human tear fluid. PhD Thesis, 1992: 35-36.

15. Wecke J, Lahav M, Ginsburg I, Giesbrecht P. Cell wall degradation of Staphylococcus aureus by lysozyme. Arch Microbiol 1982; 131: 116-123.

16. Ellison RT, Giehl TJ. Killing of gram-negative bacteria by lactoferrin and lysozyme. J Clin Invest 1991; 88: 1080-1091.

17. Reynolds BL, Rowley D. Sensitization of complement resistant bacterial strains. Nature 1969; 221: 1259-1261.

18. Leitch EC, Harris NY, Corrigan KM, Willcox MDP. Identification and enumeration of staphylococci from the eye during soft contact lens wear. Optom Vis Sci (in press).

19. Mirejovsky D, Patel AS, Rodriguez DD, Hunt TJ. Lipid adsorption onto hydrogel contact lens materials. Advantages of Nile red over oil red $\mathrm{O}$ in visualization of lipids. Optom Vis Sci $1991 ; 68$ : $858-864$.

20. Sack RA, Tan KO, Tan A. Diurnal tear cycle: evidence for a nocturnal inflammatory constitutive tear fluid. Invest Ophthalmol Vis Sci 1992; 33: 626-640.

21. Duhaiman AS. Purification of camel milk lysozyme and its lytic effect on Escherichia coli and Micrococccus lysodeikticus. Comp Biochem Physiol 1988; 91B: 793-796.

22. Spik G, Cheron A, Montreuil J, Dolby JM. Bacteriostastis of a milk-sensitive strain of Escherichia coli by immunoglobulins and iron-binding proteins in association. Immunology 1978; 35: 663-671.

23. Carter P. Spectrophotometric determination of serum iron at the submicrogram level with a new reagent (ferrozine). Anal Biochem 1971; 40: 450-458.

24. Miles AA, Misra SS, Irwin JO. The estimation of the bactericidal power of the blood. J Hyg 1938; 38: 732-748.

25. Spitznagel JK. Antibiotic proteins of human neutrophils. $J$ Clin Invest 1990; 86: 1381-1386.

26. Thakur A, Willcox MDP, Morris CA, Holden BA. Inflammatory components of human tear fluid. Aust NZ $J$ Ophthalmol 1996; 24 (2 Suppl): 13-16.

27. Anderson BF, Baker HM, Norris GE, Rice DW, Baker EN. Structure of human lactoferrin: crystallographic structure analysis and refinement at 2.8 angstrom resolution. $J \mathrm{Mol}$ Biol 1989; 209: 711-734.

28. Lindsay JA, Riley TV. Staphylococcal iron requirements, siderophore production, and iron-regulated protein expression. Infect Immun 1994; 62: 2309-2314.

29. Craig JP, Tomlinson A. Effect of age on tear osmolality. Optom Vis Sci 1995; 72: 713-717. 